\title{
Tropical Concept As Contextual Architectural Design Strategy (Case Study: Becah Resort Architecture In Nusa Penida Island, Bali)
}

\author{
I Kadek Merta Wijaya ${ }^{1^{*}}$, Windy Theja ${ }^{2}$ \\ Universitas Warmadewa, Denpasar, Bali-Indonesia \\ \{amritavijaya@gmail.com¹,windy.theja@gmail.com²
}

\begin{abstract}
Tourism in Nusa Penida has good prospects and can still be developed more optimally. Diverse attractions are one of the potentials in the tourism sector in Nusa Penida. The beauty of the islands and beaches in Nusa Penida makes the visits of domestic and foreign tourists continue to increase every year. The development of potential land use is not maximal, this is related to the unfulfilled facilities of complete accommodation for tourists. But as tourism activities increase and tourism will increase, it will certainly be accompanied by the growth of tourist accommodation at every potential point in Nusa Penida, so it is necessary to think about the presence of contextual tourism architecture. In designing beach resort using a tropical architecture approach responsive to climate, responsive to tourism potential and pay attention to the characteristics of the area in Nusa Penida. Through the design of Beach Resort with the strong character of Nusa Penida, tourists can experience the holiday with a full experience from the context of the location as well as accommodation that can only be felt in Atuh Beach, Nusa Penida. Beach Resort is designed to provide complete facilities in the form of, residential facilities, marine tourism facilities, leisure facilities, relaxation, sports, and entertainment. The results of this planning review the specifics of the building namely tread processing pattern, entrance concept, mass concept, facade concept, circulation concept, outdoor space, indoor space, air conditioning and lighting of the building, selection of ecological materials, and sanitation system. Based on all these aspects can influence each other in producing the design of Beach Resort with a tropical architectural concept. The tropical concept is realized by the design of Beach Resort which pays attention to the aspects of visual comfort or (lighting) and thermal comfort in the building so that tourists can achieve physical comfort.
\end{abstract}

Keywords: Beach Resort; Contextual Architecture; Nusa Penida Island; Tropical Architecture

\section{Introduction}

Nusa Penida belongs to the triangle of coral reefs with the highest marine diversity in the world, the emergence of predictable mola-mola fish in Nusa Penida and manta rays that can always be found throughout the year making the island a top destination for tourists from different parts of the world [1]. In addition to the marine ecosystem offered as a tourist attraction, Nusa Penida also developed marine ecotourism that presents marine ecosystems in the form of mangrove forests, coral reefs, flora, and fauna both at sea and coastal areas. 
Various activities that tourists can do in Nusa Penida such as beach recreation, diving and snorkeling, fishing, flying fish, Para-Sailing, kayaking, sea-walker, and other beach activities [1]

Marine tourism activities conducted on Nusa Penida Island can take place due to good environmental conditions and the potential for abundant natural resources to continue to be explored, this causes tourist visits to Nusa Penida to continue to increase every year. The average total tourist visits to the Nusa Penida area from 2011 to October 2019 (Last 9 Years) amounted to 207,977 people/ year or an estimated 200,000 tourists visit Nusa Penida every year [2]

However, there are problems where the development of potential land use is not maximal, this is related to the unmet facilities of complete accommodation for tourists. Also, the climatic conditions in Nusa Penida have a considerable influence on the world of tourism, both on the attraction and the preferences of visiting tourists [3]

The tourism sector is so sensitive to the climate that tourists need to carefully count the exact time of visit. Rising temperatures could threaten the sustainability of tourism activities and marine biodiversity in coastal tourist destinations. The presence of climate change can cause tourist comfort to be disturbed so that it has implications for tourist visit patterns as well as changes in perception sparked by damage to the physical condition of tourist attractions offered [4]

Any activity or activity of tourism, especially irresponsible marine tourism activities can threaten the survival of marine life and further damage the tourist attraction itself. Also, in coastal areas there will be easy abrasion, resulting in drastic environmental changes and the absence of protection of coastal areas. The pollution that occurs not only damages the sea but also threatens human health.

Therefore, a Beach Resort design with a tropical architecture approach that is responsive to the climate, responsive to tourism potential, and pay attention to the characteristics of the area in Nusa Penida. The facility is a beach resort designed to be able to adjust to the climate and environment. Besides, this beach resort can become a marine tourism destination with ecotourism insight, so that tourists can still enjoy the beauty of nature without any concern there is any indication of the destruction of marine ecosystems in the area.

\section{Literature Review}

The resort can be interpreted as a planned area located on land related to tourist attractions, which has a function that is as a place to stay, rest, and recreation with additional special facilities. Special facilities can be sports, convention, religious, and other business purposes. According to [5]. Beach Resort is a resort located in the beach area. Water sports facilities are a major consideration in the building of beach resorts. Facilitated sports facilities include parasailing, windsurfing, and scuba trails.

Tropical architecture is the architecture that leads to problem-solving posed by tropical climates such as sun, high temperatures, rain, and high humidity [6]. Tropical architecture is expected to be able to answer all climate issues through a highly varied design form with a wide range of possibilities. Aspects of visual comfort or (lighting) and thermal comfort are the two dominant aspects that need to be considered in the building for residents to achieve physical comfort. 


\section{Research Method}

The steps are taken in this discussion consist of two stages, namely:

\subsection{Data Collection Stage}

The study of literature, which is the stage of data collection through literature related to the theme of modern tropical architecture in the form of supportive theories, standardization, and other data.

The analysis phase, which is done based on three aspects, namely: the aspect of activities and the system of space needs, and other things that suit the needs of the design. The condition and potential aspects of the environment are analyzed of various things related to the location of the design both on the site and the state of the surrounding environment. The building system aspect is an analysis of various things related to the building that will be established both from the physical of the building, the system, and other requirements.

\subsection{Concept Stage}

It is the conclusion of an interconnected synthesis that is then developed in the form of a design concept, and continued at the design stage to realize in three-dimensional form. The resort can be interpreted

\section{Results and Discussions}

The selected location is in the land use system which is an area dedicated to the tourism area. The site has an area of 3.6 hectares. The location of the site is on Atuh beach, Pejukutan Village, Nusa Penida District, Klungkung Regency

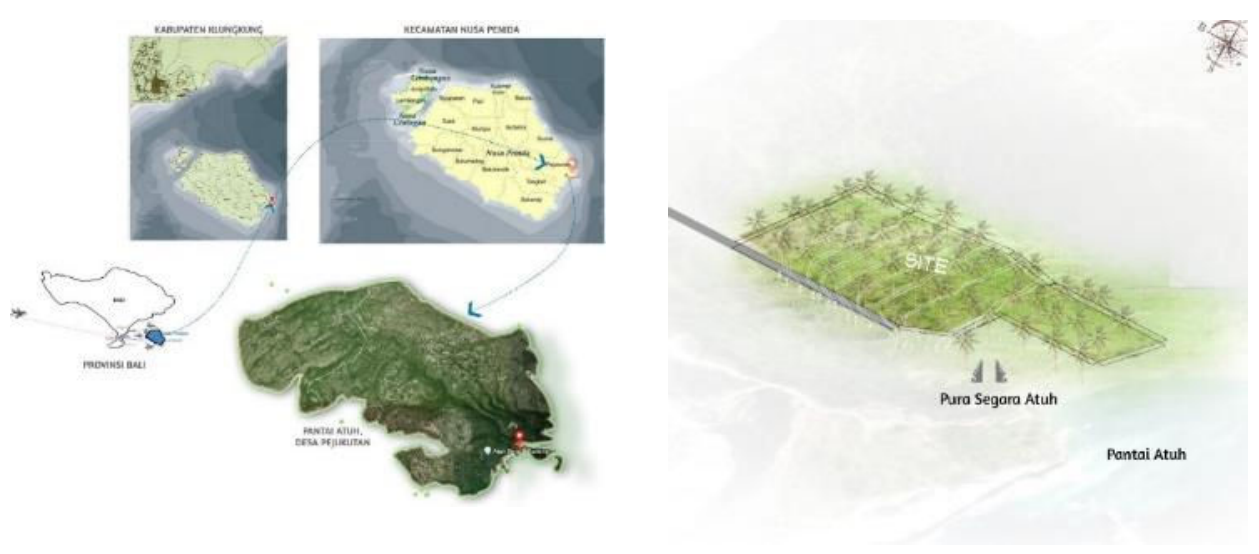

Figure. 1 Planning Area Location

\subsection{Zoning Concept}

a. Analysis 


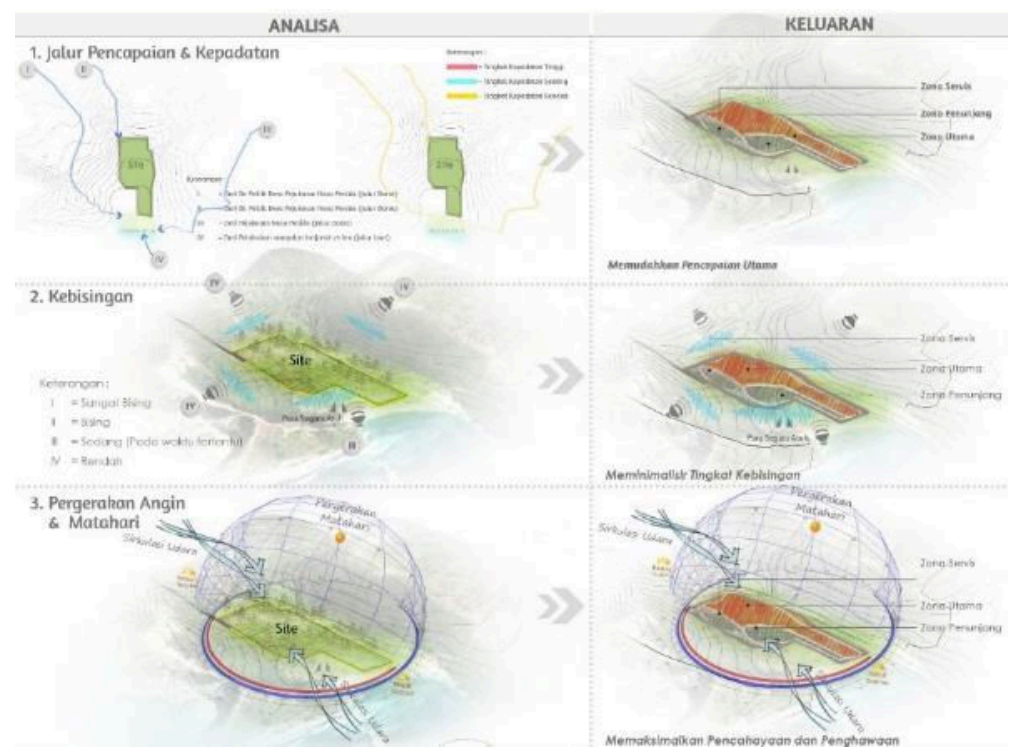

Figure. 2 Zoning Laying Analysis

Based on the analysis image above, it can be spelled out as follows:

- Based on achievement path and a traffic density level

The main achievement route on the landline is Banjar Pelilit Pejukutan Village, Nusa Penida where this road has the easiest access to the site. The second major achievement is by sea from Sampalan port is $25 \mathrm{~km}$ away. So if viewed from the achievement path then the position of the service zone/public is close to the main achievement path, so it will facilitate the achievement of the site.

- Based on Noise Level

The noise level on the site is influenced by the factors of the activity of the surrounding community, the highest noise level comes from the east, noise occurs at certain times i.e. if there are religious activities in Segara Atuh Temple. The noise level is low because the surrounding site is flanked by a stretch of cliffs and empty land. If based on the noise around the site then the placement of the main zone should be in an area that has a low noise level, so the placement of the main zone is in the north-west area of the site (red zone).

- Based on Wind and Solar Movement

Wind movement at the site is in the morning to noon blowing from east to west, while in the afternoon to evening it blows from the opposite direction which is west to east. The movement of the sun on the site is rising from the east at $05.30 \mathrm{AM}$ and setting in the west at 6:00 PM. Based on the movement of the sun and wind on the site, the placement of the main zone is to the north of the site, to maximize lighting and air conditioning.

b. Result of Zoning 

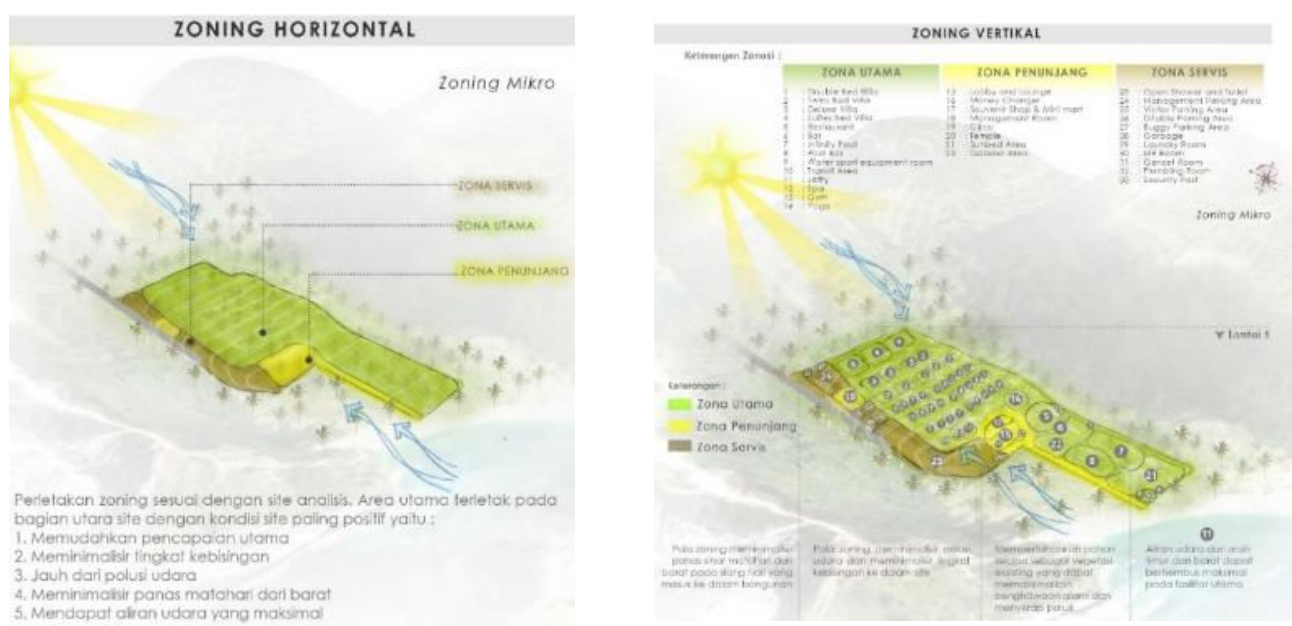

Figure. 3 Makro and Mikro Zonning

\subsection{Entrance Concept}

a. Entrance Laying Analysis

Based on the image, the entrance is determined based on the path of achievement on the site. Where to get to the site can go through 2 lines namely: land mainline (Yellow) and sea path (Blue).

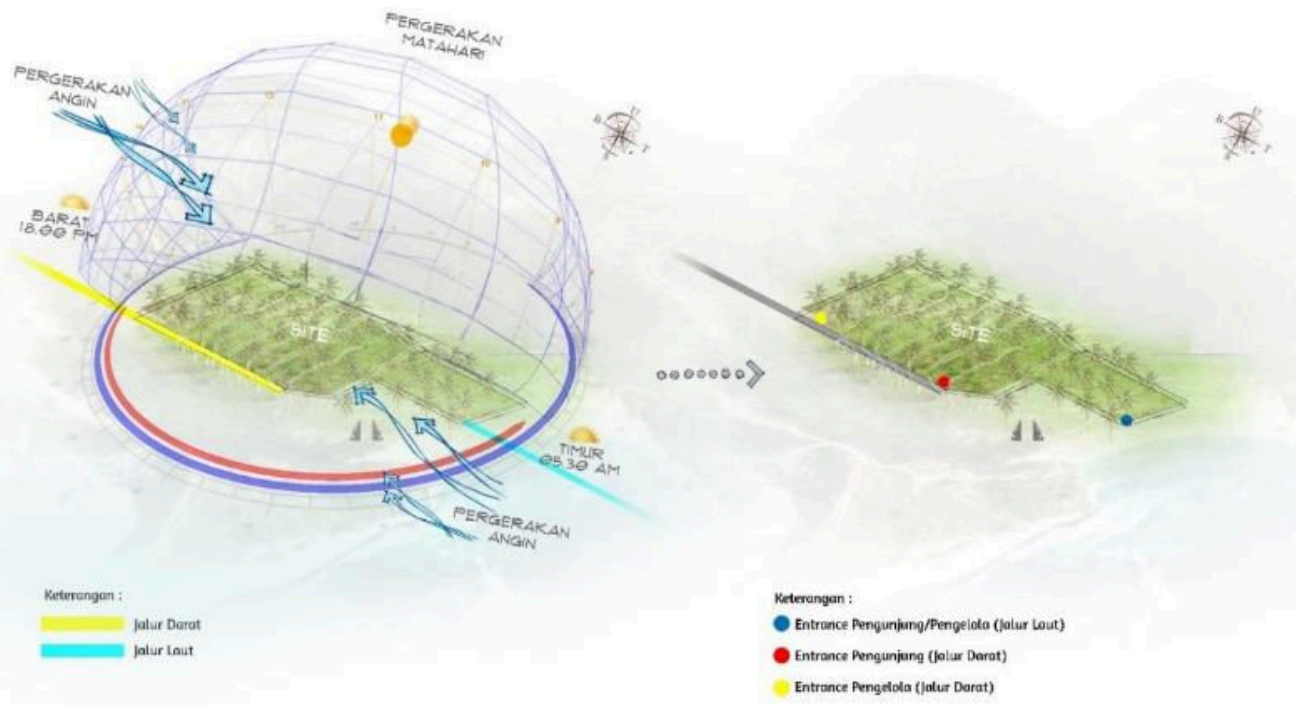

Figure. 4 Entrance Laying Analysis 
b. Entrance Form Analysis

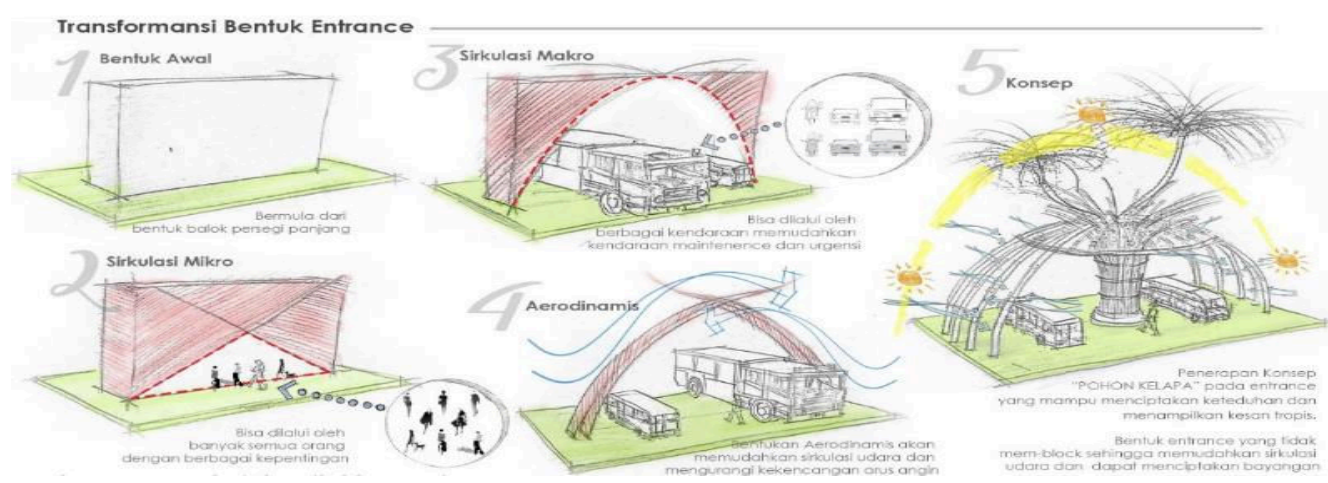

Figure. 5 Entrance Form Analysis

Here is an explanation of the transformation of the entry form:

- Initial form, the initial shape is a rectangular shape, which is the beginning of the entrance shape.

- Microcirc circulation, microcirc circulation in question is pedestrian circulation, disability circulation, and circulation of two-wheeled vehicles. The effect of microcirc circulation is the absence of holes for access according to the needs of circulation.

- Macro circulation, the macrocirculation in question is the circulation of four-wheeled vehicles, service vehicles, and emergency vehicles. Where the vehicle has a large size, so that in the shape of the entrance will enlarge according to the size of the vehicle through which it is 10 meters to be accessed by two vehicles in and out.

- Aerodynamic shape and air circulation, for the entrance to adjust to the surrounding climate conditions, then to anticipate the load due to the wind, in the form of entrance will be made holes randomly so as not to block the circulation of air on the site while strengthening the entrance when hit by high-pressure wind. The resulting shadow will also serve as a shaded area.

- Application of concepts, the application of the concept of "Shade of Coconut Tree" is to take the form of a coconut tree that can create shade and a tropical impression.

- Theme implementation, the application of tropical architecture themes by adjusting the shape to the surrounding climate conditions, the use of environmentally friendly materials, and adapting to the needs. 


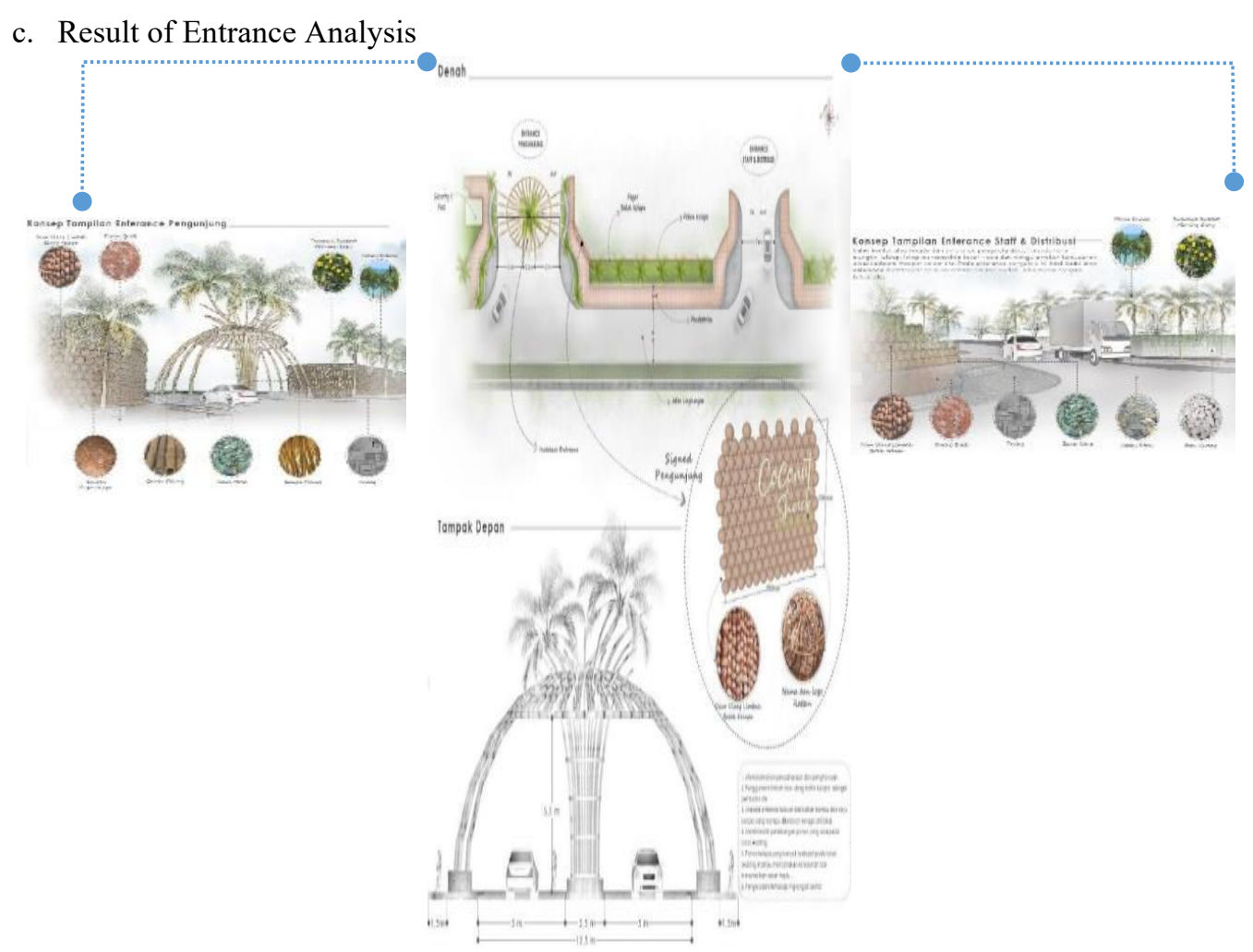

Figure. 6 Entrance Form

\subsection{Massa Concept}

a. Determination of Mass Organization

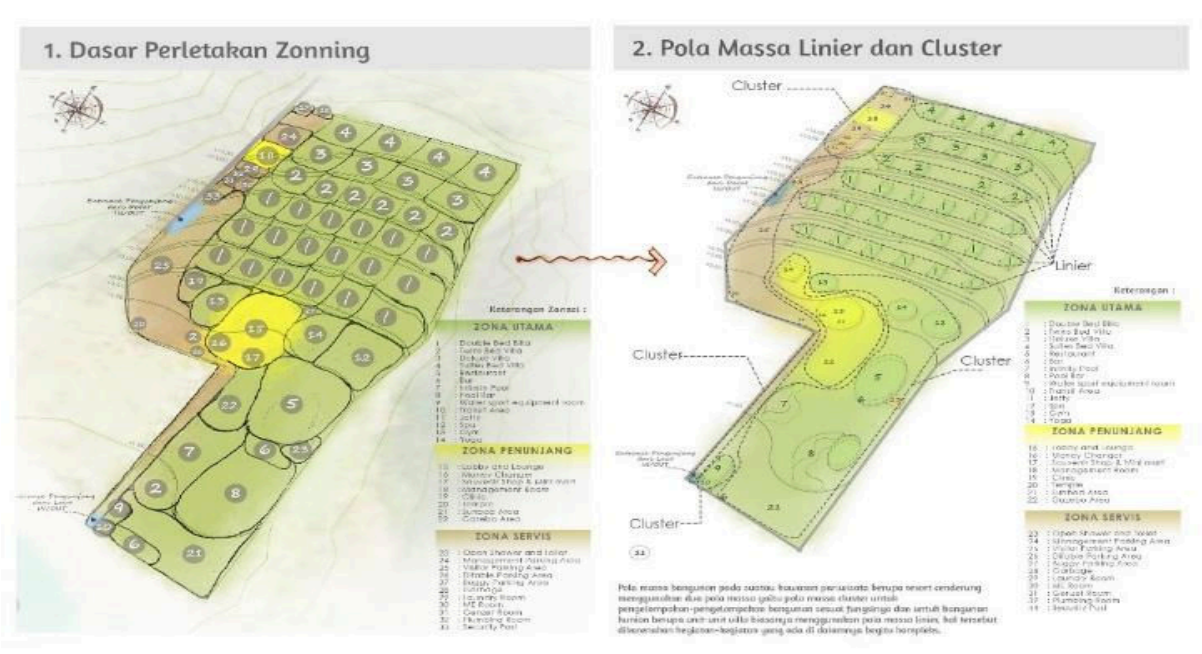

Figure. 7 Mass Organization 
Based on zoning's previous output, where the main zone is located to the north of the site and around it there is a support zone and service. From the zoning, two mass patterns are used, namely, cluster mass patterns for groupings of buildings according to their function and for residential buildings in the form of villa units using linear mass patterns, because the activities inside are so complex.

b. Mass Pattern Analysis

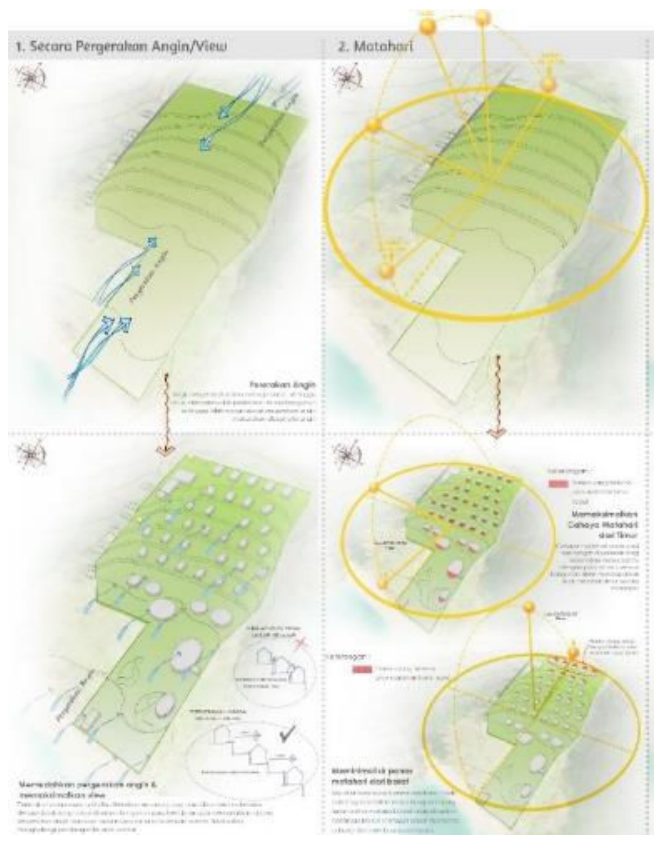

Figure. 8 Mass Pattern Analysis

Based on the analysis image above, it can be spelled out as follows:

- By Wind Movement/view

Wind movement at the site is in the morning to noon blowing from east to west, while in the afternoon to evening it blows from the opposite direction which is west to east. Based on the movement of the wind on the site, the mass placement of villa units is placed zig-zag and made openly with sufficient distance between buildings that aim to facilitate the movement of the wind and also so that the mass of each other does not block each other's view towards the beach.

- In the Movement of the Sun

The movement of the sun on the site is rising from the east at $05.30 \mathrm{AM}$ and setting in the west at 6:00 PM. Based on the movement of the sun on the site, the placement of mass patterns will maximize sunlight from the east and minimize the sun's heat from the west. 


\section{c. Mass Form Transformation}

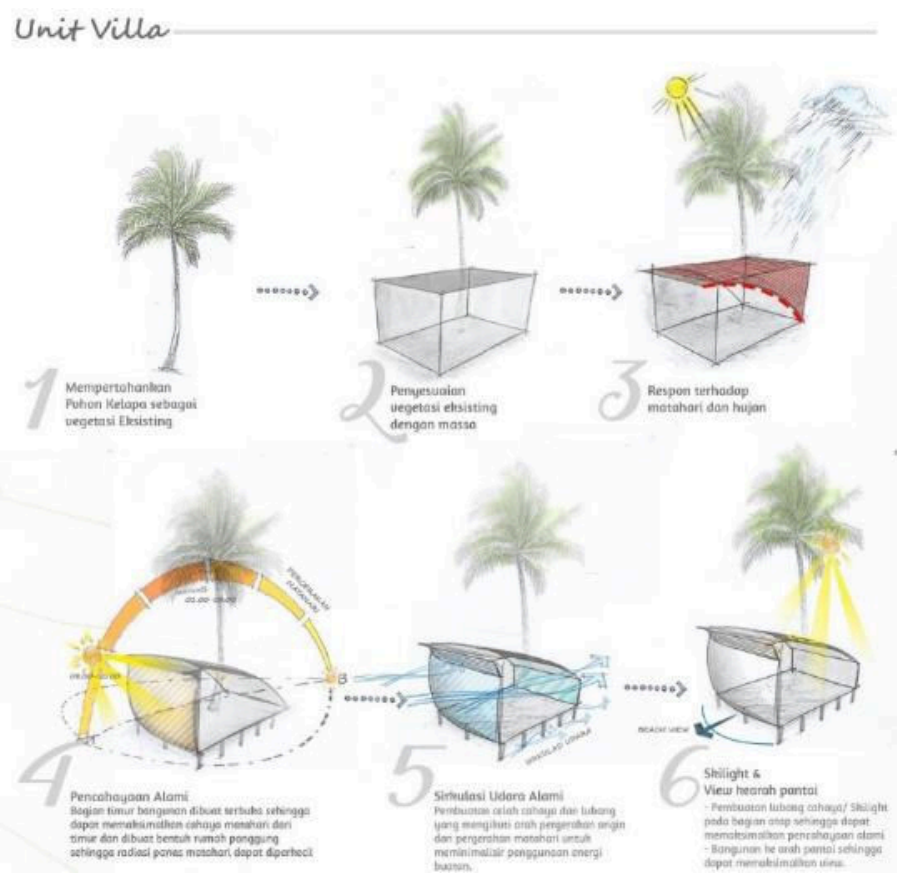

Figure. 9 Mass Form Transformation

Here is an explanation of the transformation of the mass form:

- Maintain coconut trees as existing vegetation

- Adjustment of existing vegetation with mass

- Response to sun and rain

- Natural lighting and stage houses

The eastern part of the building is made open to maximize sunlight from the east. The building is made to form a stage house so that the heat of solar radiation can be reduced

- Natural Air Circulation and Stage House

The creation of light gaps and holes that follow the direction of wind movement to minimize the use of artificial energy in buildings.

- Skylight and view towards the beach

The making of a skylight on the roof of the building, to maximize natural lighting. As well as the orientation of the building towards the beach to maximize the view.

d. Result of Mass Pattern

Mass orientation is determined based on the results of the analysis of climatic conditions on the site. Based on the results of the analysis, the direction of mass orientation is to the eastfacing towards Atuh Beach, where this orientation aims to maximize the view, lighting, and air conditioning of the building. 


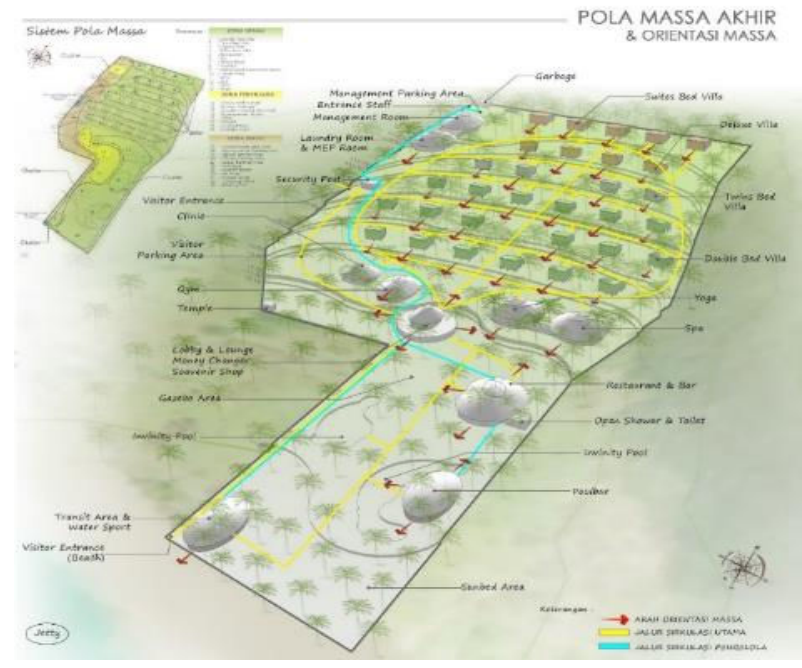

Figure. 10 Mass Patter

\subsection{Facade Concept}

a. Form Facade Analysis

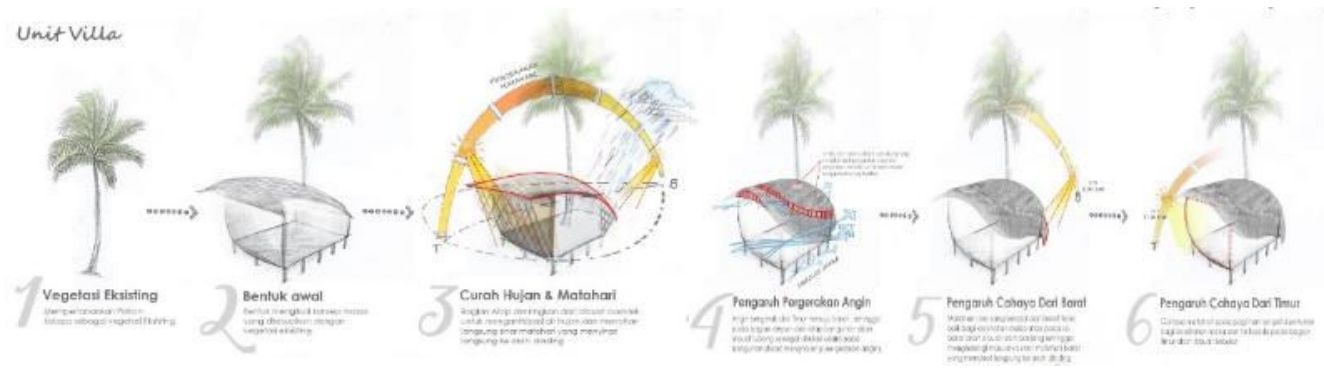

Figure. 11 Fasade Form Analysis

Here is an explanation of the picture above:

- Exciting vegetation, maintaining coconut trees as existing vegetation

- Initial form, the initial shape adjusts to the output of the mass shape adjusted to the existing vegetation (Coconut Tree).

- Rainfall and Sun, to facilitate the flow of rainwater, the roof is tilted, and made overstep to withstand direct sunlight shining towards the wall

- Effect of Wind Movement, the wind movement on the site is from east to west, and vice versa. To maximize the air conditioning on the building, a hole will be made in the direction of airflow on the site so as not to block the movement of the wind.

- The Influence of Light from the East, the heat of light from the east is needed for health, to be able to maximize it then the facade on the east is made open to capture the light and heat to the maximum. 
- The Influence of Light from the West, to minimize excessive solar heat from the west, the roof on the west side will be made longer to block the entry of western sunlight that illuminates directly towards the wall.

- Application of Themes and Concepts, "Buah Kelapa (Nyuh Pongpongan)" consists of layers where the first layer is the deepest is the flesh of the fruit likened to a wall on the villa building, then the second, third, and fourth layers on the coconut are likened as 3 layers of the roof in the villa building. And the hole in the pongpongan is likened to the skylight hole of the building and the place where the coconut trees grow that melt the boundaries of the indoor space and the outer space. While the application of the theme is to maximize the lighting and air conditioning naturally on the building façade.
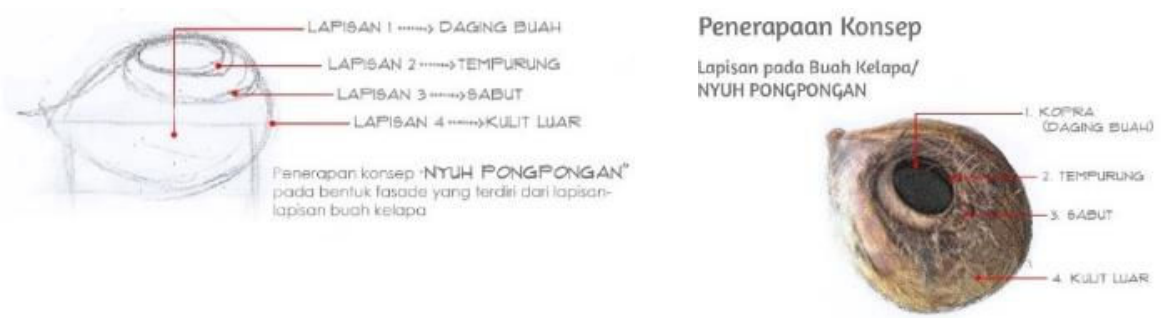

Figure. 12 Implementation of Mass Concept

b. Result of Facade Analysis

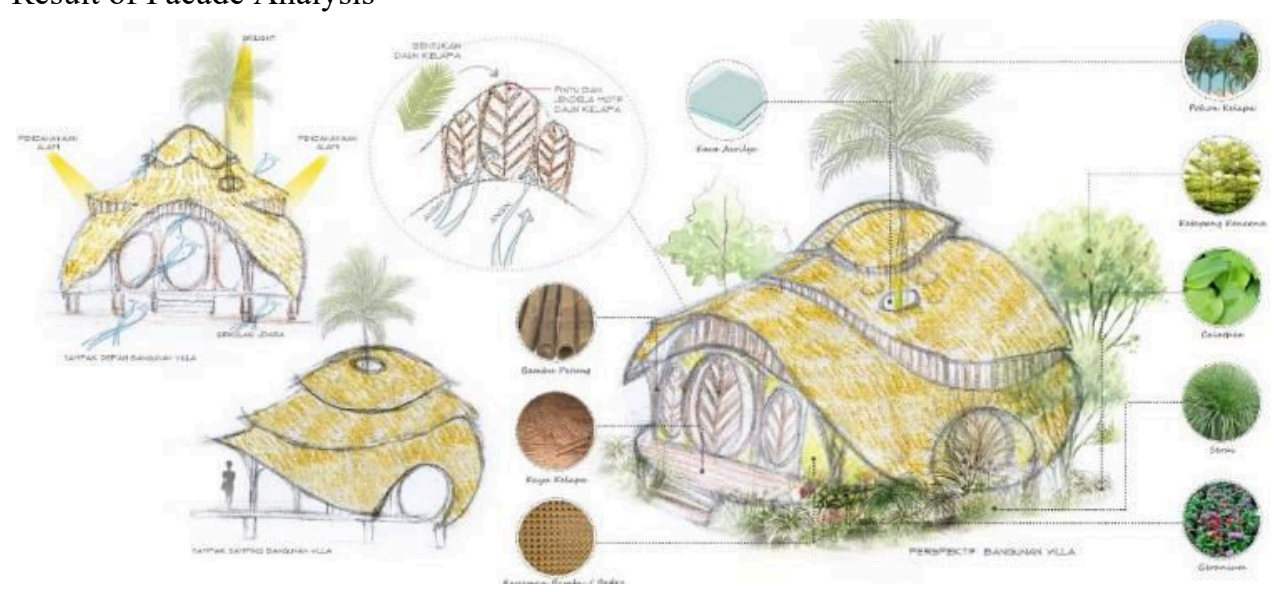

Figure. 13 Facade Output in Villa Unit

Materials used in buildings are green materials or environmentally friendly materials. The principle of tropical materials is,

- Renewable resources

- Low energy process

- Local ability (produced in the area)

- Recycle content (recyclable)

- Remanufacture (re-manufactured) 
Thus the materials used in the design are coconut wood and bamboo as the material of the whole building. And combined with natural materials namely grass block, paving block, paving stone, sand beach

\subsection{Circulation Concept}

- Circulation by Civitas, circulation based on civitas is grouped into two namely visitor circulation and circulation manager.

- Circulation by Vehicle Type, circulation by vehicle type is divided into 5 namely, circulation of bicycle circulation, motorcycle, car circulation, bus circulation, and circulation of service and emergency vehicles.

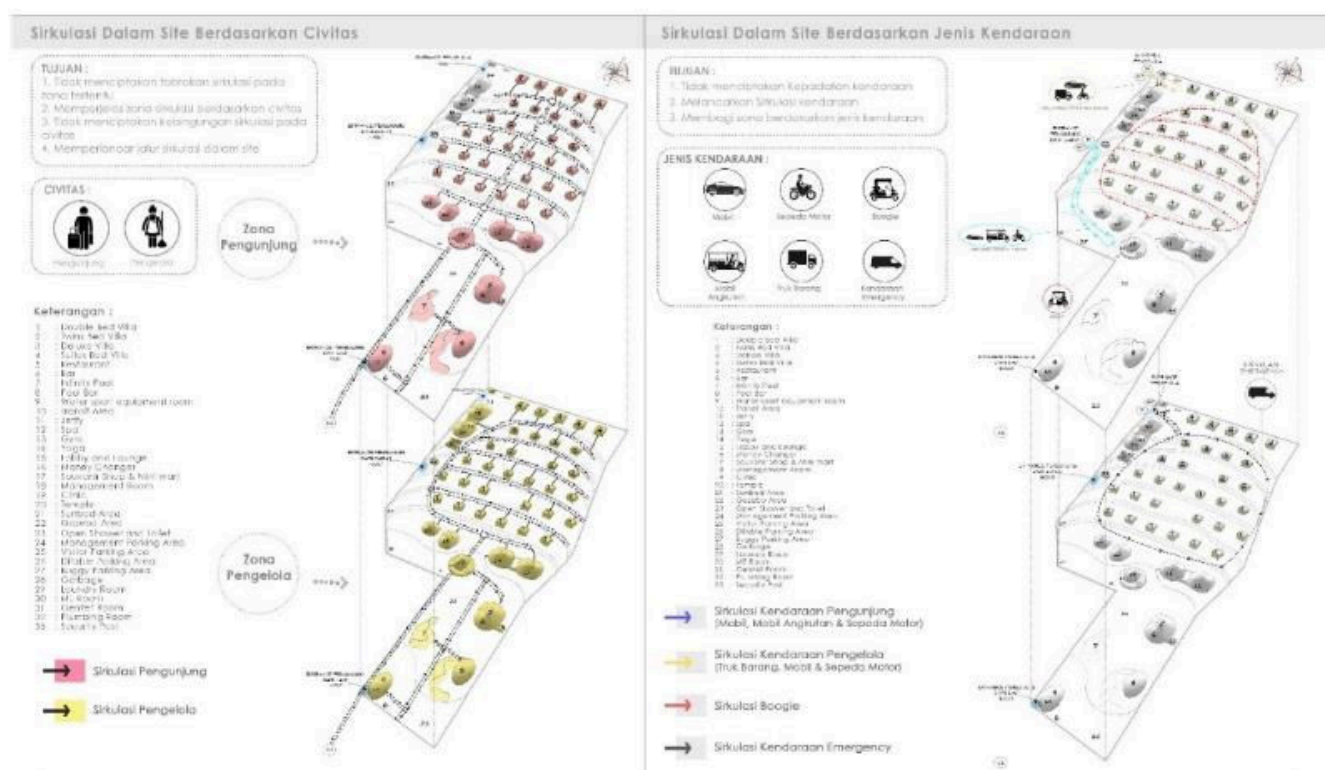

Figure. 14 Circulation Concept

\subsection{Circulation Concept} bar.

The concept of outdoor space in the gazebo area, parking area, sunken pool, and pool

- Gazebo Area

The gazebo area is made environmentally friendly by the way of the normalizing of vegetation and the use of environmentally friendly materials, such as reeds as roof coverings, coconut wood, and bamboo as construction. In the gazebo area of coconut trees will be retained so that it can create an atmosphere that blends with nature.

- $\quad$ Parking Area

The parking area is made to be safe and protected from the heat of the sun. Where will the brewing plant be planted between the parking row? In the form of trees and perdu that can absorb pollution. Parking areas are also available for parking supporting facilities, such as parks, pedestrian, driver waiting areas. For hardening using grass blocks, there are sand pads and foundations underneath so that they can absorb water.

- $\quad$ Sunken Pool 
The sunken pool serves as a seating area for resort visitors. This seating area is designed to be on the surface of the water, the water used in the pool uses seawater, and can be used as air conditioning with an evaporate solar heat evaporation system. The use of local materials is a rock as a seating area.

\section{- Pool Bar}

The Bar is made environmentally friendly by the way of the normalizing of vegetation and the use of environmentally friendly materials, such as reeds as roof coverings, coconut wood, and bamboo as construction. In the pool area use coral reefs as hardening and planted vegetation to create healthy air.

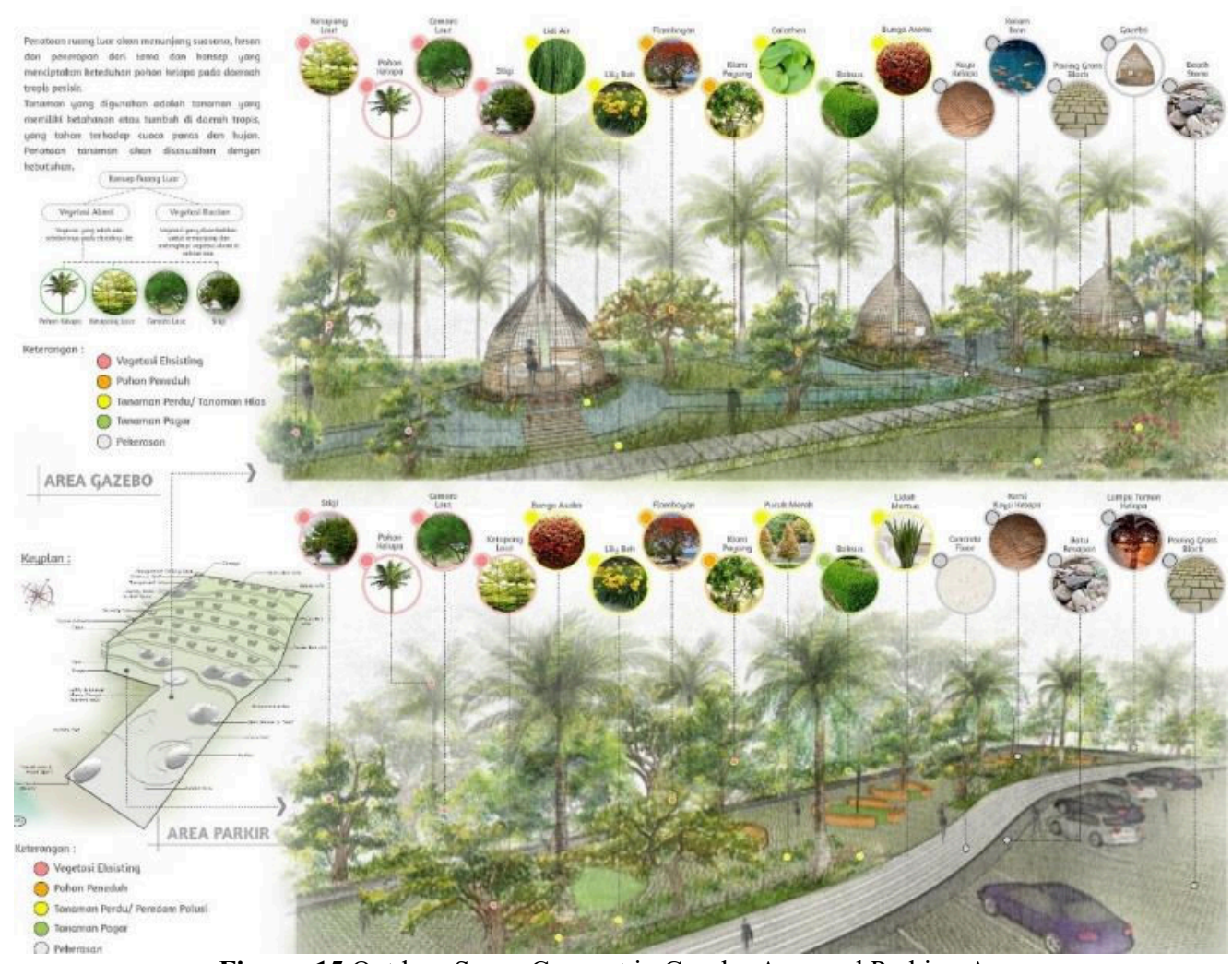

Figure. 15 Outdoor Space Concept in Gazebo Area and Parking Area 


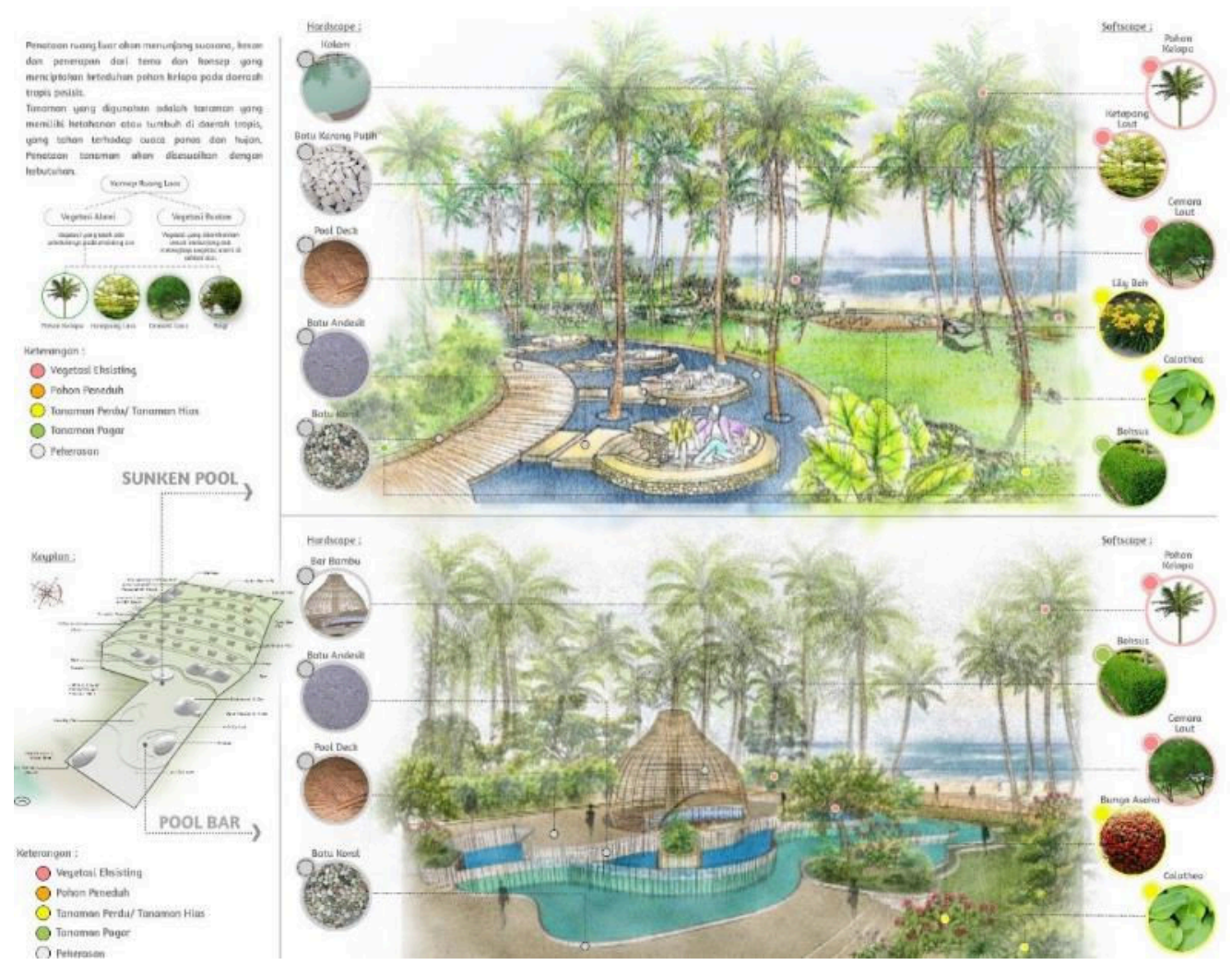

Figure. 16 Outdoor Space Concept on Sunken Pool and Pool Bar

\subsection{Interior Concept}

The hardening element used in deep space is to use natural materials, easy to apply, easy in maintenance, high durability, and environmentally friendly. The application of topical themes to the villa by maximizing lighting and air conditioning naturally, for natural lighting using skylights with acrylic glass material aims to prevent rainwater from entering the building. As for natural air conditioning using ventilation in the form of a poster on the roof. The application of the concept is seen from the design of the deep space that retains coconut trees at every mass of the building to create an atmosphere of deep space that blends with nature. 


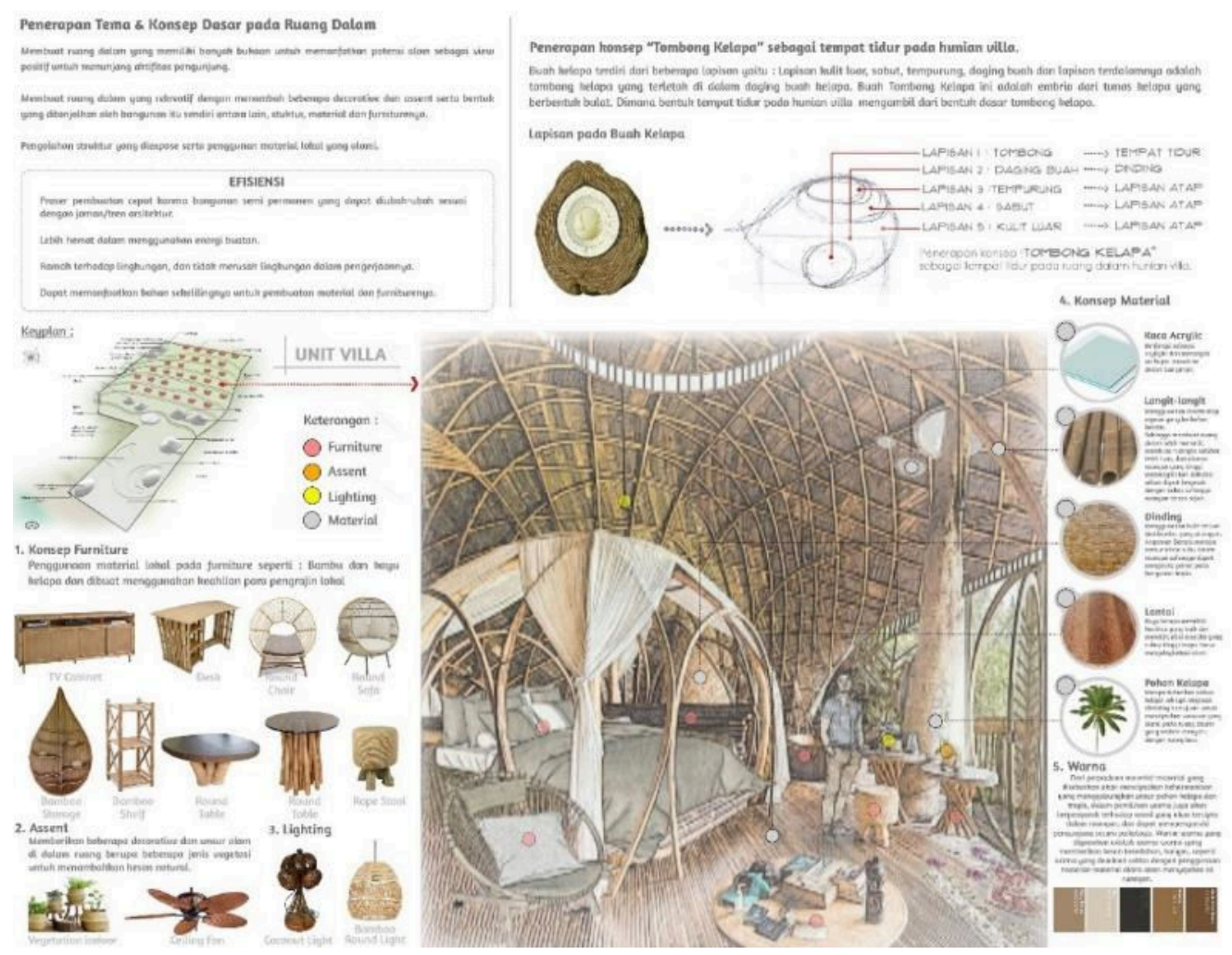

Figure. 17 Interior Concept in Villa Unit

\subsection{Utility Concept}

The output of the utility system is divided into several parts, namely:

a. Lighting

- Natural lighting

Natural lighting is an important thing to look out for while emphasizing the theme of coastal tropical architecture. Here is an analysis in determining natural lighting at Beach

- Analisa

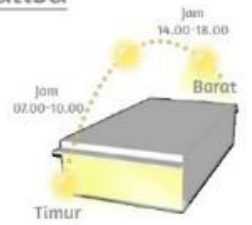

Pencahayaan alami dari timur-barat

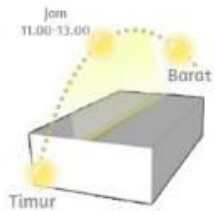

Pencahayaan alami dari atas

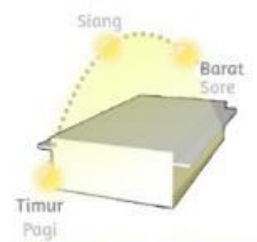

Pencahayaan alami dari samping

Resort:

Figure. 18 Natural Lighting Analysis 
Based on the image above there are three directions of natural light capture that are from the east, upper center, and west. So from the analysis, it produces the following natural lighting:
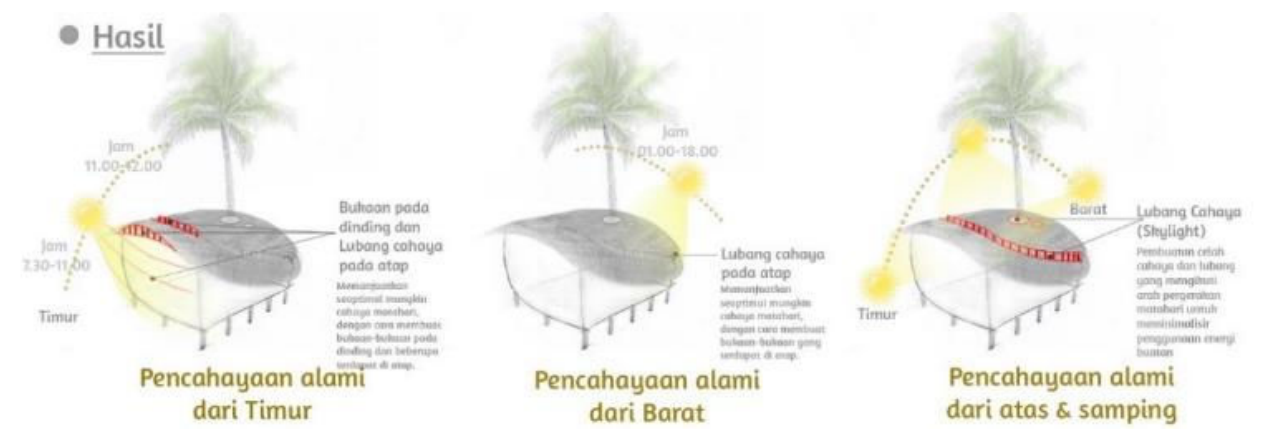

Figure. 19 Result of Natural Lighting Analysis

- $\quad$ Artificial Lighting

Artificial lighting will be minimized, whereby the use of this lighting is only for the night while during the day does not use (except in certain areas). The output of artificial lighting analysis is:
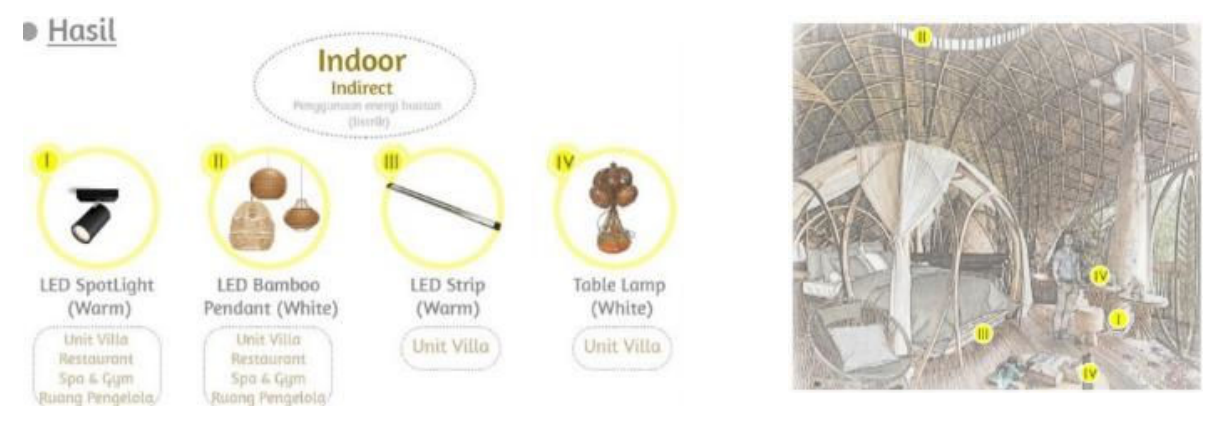

Figure. 20 Types Of Artificial Lighting On The Interior

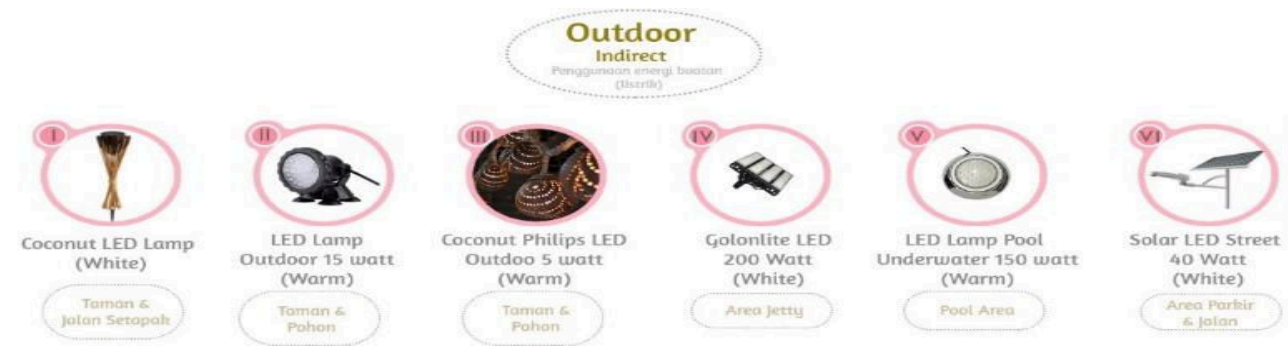

Figure. 21 Types Of Artificial Lighting On The Outdoor 
b. Natural Air Conditioning

Natural air conditioning will be maximized in each building, this aims to reduce the use of artificial air conditioning while creating environmentally-friendly buildings. The natural air conditioning system applied is with cross ventilation or cross-system. Given the wind conditions on the site blow well because the site is in the coastal area and the high seas then natural air conditioning in the form of wind is utilized as much as possible. Air conditioning is done by providing openings to buildings both windows and air vents. It does not block the air movement path by creating ventilation holes from the east and west directions so that the center of the building will be able to receive maximum natural air conditioning. Ventilation holes are ventilation and openings are found on the roof.

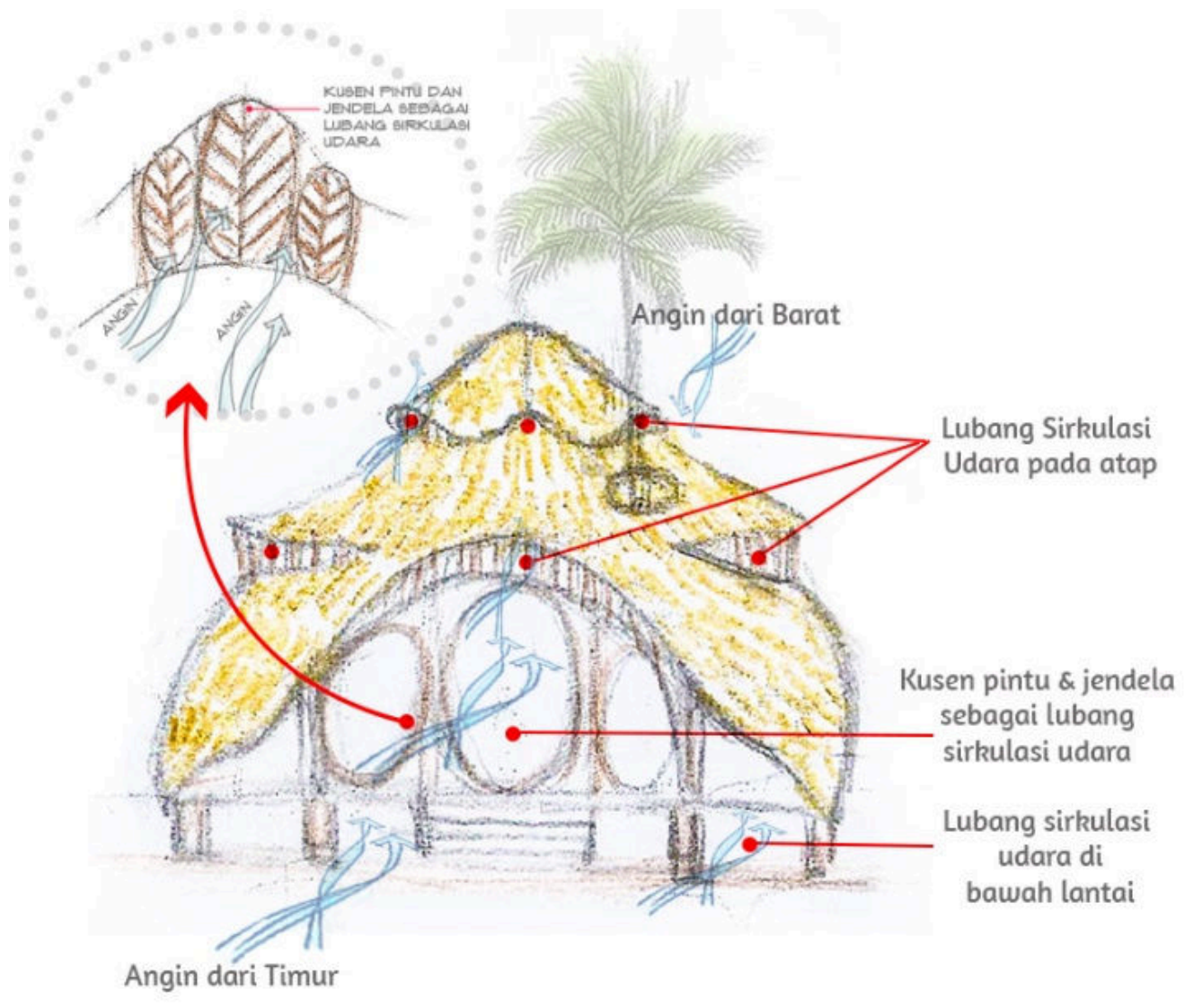

Figure. 22 Natural Air Conditioning on Buildings

\section{Conclusion}

The implementation of Tropical Architecture in the design form of Beach Resort in Atuh Beach, Nusa Penida is expected to be able to answer all climate issues, taking into account 
aspects of visual comfort or (lighting) as well as thermal comfort in buildings so that tourists can achieve physical comfort. The application of concepts where mass order, material selection, and color are taken from the ideas of the shapes found in nature and applied to the design object. Thus the design object will have tropical elements that blend with the surrounding nature. The design also provides opportunities for local tourism areas and local communities in developing the potential of regions and individuals to support regional income in the tourism sector.

\section{References}

[1] P. K. Klungkung, Rencana Pengelolaan KKP Nusa Penida. Klungkung: KKP Nusa Penida, 2012.

[2] D. P. K. Klungkung, Jumlah Kunjungan Wisatawan ke Nusa Penida. Klungkung: Dinas Pariwisata Kabupaten Klungkung, 2019.

[3] J. M. Hamilton, D. J. Maddison, and R. S. J. Tol, "Climate change and international tourism: A simulation study," Glob. Environ. Chang., 2005.

[4] N. Suwarno, "Model Pengembangan Tata Ruang Kawasan Objek Wisata Air, Studi Kasus: Objek Wisata Air Jolotundo, Klaten," J. Mns. dan Lingkung., vol. 16, no. 1, pp. 1-11, 2009.

[5] E. Marlina, Panduan Perancangan Bangunan Komersil. Yogyakarta: Andi Offset, 2008.

[6] T. H. Karyono, "Kenyamanan Termal dalam Arsitektur Tropis," Researchgate, 2016. 